\title{
Eksplorasi Penilaian Pendekatan Pasar Untuk Penentuan NJOP PBB Perusahaan di Kabupaten Pasuruan
}

\author{
Ika Ratnawati, Ali Djamhuri, Nurkholis \\ Program Magister Akuntansi PascasarjanaFakultas Ekonomi dan Bisnis Universitas Brawijaya Malang \\ Program Magister Akuntansi PascasarjanaFakultas Ekonomi dan Bisnis Universitas Brawijaya Malang \\ Program Magister Akuntansi PascasarjanaFakultas Ekonomi dan Bisnis Universitas Brawijaya Malang
}

\begin{abstract}
ABSTRAK
Penelitian ini menyangkut penilaian properti oleh Pemerintah Kabupaten Pasuruan tahun 2014 yang bertujuan menentukan Nilai Jual Objek Pajak (NJOP) Pajak Bumi dan Bangunan (PBB) 2015 dalam rangka meningkatkan PAD Kabupaten Pasuruan yang dilakukan dengan menggunakan pendekatan pasar. Penelitian ini merupakan suatu action reaserch untuk mengaplikasikan teori - teori penilaian dalam praktek penilaian yang dilakukan oleh Pemda Kabupaten Pasuruan pada tahun 2014 untuk NJOP PBB tahun 2015 tersebut. Action reaserch dilakukan oleh peneliti untuk menjawab pertanyaan tentang bagaimana teori penilaian properti dilaksanakan di lapangan. Hasil penelitian yang dilakukan oleh peneliti menemukan bahwa penilaian perusahaan yang dilakukan Pemda Kabupaten Pasuruan di akhir tahun 2014 dengan tujuan penentuan NJOP PBB 2015 yang merupakan pendekatan pasar belum sesuai dengan Standar Penilai Indonesia. Terdapat dua faktor yang mempengaruhi NJOP PBB tahun 2015, yaitu faktor internal yang terdiri dari lokasi objek pajak dan keadan fisik objek penilaian serta faktor eksternal yang kebijakan pemerintah dan permintaan pasar.
\end{abstract}

Kata Kunci : Penilaian properti, pendekatan pasar, NJOP PBB

\section{ABSTRACT}

This research involves the property valuation done by the Regency Government of Pasuruan in 2014. In which, the purpose of this appraisal is deciding the selling value of tax object (NJOP) from the property tax(PBB) in 2015. This research is kind of action research done to apply the appraisal theories in a practical appraisal done by the Regency Government of Pasuruan in 2014 for the selling value of tax object from the property tax in 2015. This action research was done by the researcher to answer how the theory of Property valuation is applied. The result of the research done by researcher detected the company's appraisal done by the Regency Government of Pasuruan in the end of 2014 with the intention of selling value of tax object from the property tax determination 2015 related to the market approach is inappropriate with Indonesian Appraisal Standard. There are two factors which affect the 2015 selling value of tax object from the property tax, those are the internal and external factor. The internal factor includes the location of tax object and the condition of appraisal objects. And the external factor includes the government policy and market demand.

Keywords: The property valuation, Market approach, Selling value of tax object from property tax

\section{PENDAHULUAN}

Bentuk otonomi daerah yang selaras dengan kebijakan pemerintah pusat salah satunya tercermin dari pelimpahan PBB yang diatur melalui UU No 28 Tahun 2009. Undang- Undang ini menetapkan bahwa pelimpahan PBB P2 dari Pajak Pusat menjadi PajakDaerah harus dimulai pada 1 Januari 2011 atau selambat - lambatnya pada 1 Januari 2014.

Alamat Korespondensi Penulis:

Ika Ratnawati

Email : ikaratnawati.1982@gmail.com

Alamat : Jl.MT Haryono 165 Malang
Pemerintah Daerah Kabupaten Pasuruan melaksanakan kebijakan tersebut pada 1 Januari 2013 bersamaan dengan pemungutan Bea Perolehan Hak Atas Tanah dan Bangunan selanjutnya disebut sebagai (BPHTB)

Pajak Bumi dan Bangunan dan BPHTB merupakan pajak pusat yang sebelumnya dikelolah oleh Pemerintah Pusat melalui Kantor Pajak Pratama Pasuruan dan sekarang dilimpahkan ke Dinas Pengelolaan Keuangan Daerah Kabupaten Pasuruan sebagai salah satu sumber Pendapatan Asli Daerah.Pada akhir tahun 2014 Pemda Kabupaten Pasuruan, dalam hal ini Dinas 
Pengelolaan Keuangan Daerah, melakukan penilaian untuk menentukan NJOP PBB 2015 dengan menggunakan metode pendekatan harga pasar. Penilaian dengan pendekatan pasar merupakan pendekatan penilaian utama yang dianjurkan oleh Standar Penilai Indonesia (SPI), baru jika pendekatan pasar tidak bisa digunakan pendekatan pendapatan dan pendekatan biaya digunakan. Pendekatan pasar menghasilkan indikasi nilai dengan cara membandingkan aset yang dinilai dengan aset yang identik atau sebandingyang memberikan informasi harga transaksi atau penawaran.Pendekatan pendapatan digunakan untuk menghitung properti yang memiliki atau menghasilkan pendapatan sedangkan pendekatan biaya digunakan untuk menilai properti yang memiliki konstruksi bangunan yang berbeda dengan bangunan pada umumnya.

Metode penilaian baik penilaian bisnis ataupun penilaian properti mengenal tiga pendekatan penilaian [1]. Penilaian dengan harga pasar merupakan estimasi harga properti yang bisa dibeli dan dijual melalui interaksi pembeli dan penjual di pasar tanpa ada paksaan dari kedua belah pihak, Andrew [2]. Dalam jurnal perkembangan metodologi penilaian berpendapat bahwa pendekatan harga pasar memiliki kelebihan kemudahan untuk mencari data pasar yang ada di pasar properti, tetapi dari kelebihan itu terdapat juga kekurangan menentukan apakah data pembanding yang digunakan sudah sesuai / sebanding dengan properti yang dinilai [3]. Pendekatan pendapatan menghasilkan indikasi nilai dengan mengubah arus kas dimasa yang akan datang kenilai kini [4]. Pendekatan biaya merupakan suatu pendekatan penilaian yang menggunakan dasar biaya yang dibutuhkan untuk membangun suatu properti baru kemudian disesuaikan dengan penyusutan properti tersebut [5].

Tujuan penelitian ini dilakukan untuk mengetahui bagaimana teori - teori penilaian diaplikasikan dalam praktek penilaian yang dilakukan oleh Pemda Kabupaten Pasuruan pada tahun 2014 untuk NJOP PBB tahun 2015 sehingga Pendapatan Asli Daerah Kabupaten Pasuruan dapat ditingkatkan. Pemda Kabupaten Pasuruan melakukan penilaian pada perusahaan yang baru memiliki ijin mendirikan bangunan (IMB) dan belum masuk pada surat pemberitahuan pajak terutang (SPPT) tahun 2014.

\section{METODE PENELITIAN}

Mendasarkan pada rumusan masalah, maka penelitan ini menggunakan metode penelitian kualitatif deskriptif dengan pendekatan studi kasus. Moleong pada bukunya metodologi penelitian kualitatif mencoba mendefinisikan penelitian kualitatif merupakan suatu prosedur penelitian yang menghasilkan data deskriptif berupa kata-kata tertulis atau lisan dari orangorang dan perilaku yang dapat diamati [6]. Penelitian ini memerlukan action research digunakan untuk menghubungkan teori dan praktek penilaian sehingga pertanyaan penelitian bisa terjawab seperti yang disampaikan oleh O'Brien [7]. Action research merupakan bentuk praktek kerja dari teori-teoriyang ada yang diterapkan dilapangan sebagai bentuk kerja nyata [8]. Action research yang dilakukan oleh peneliti dalam melakukan penilaian properti untuk penentuan NJOP PBB tahun 2015. Data primer yang diperoleh langsung saat penelitian berupa foto objek penelitian yang ada di siteplan, foto data pembanding dan hasil wawancara dengan manajemen building. Data sekunder diperoleh dengan menggunakan dokumentasi organisasi ataupun arsip dan data yang dipublikasikan. Dalam penelitian ini data sekundernya adalah SPPT tahun 2014 , kertas kerja, dan data transaksi BPHTB tahun 2014.

Adapun tahapan analisis data dilakukan dengan cara sebagai berikut:

1. Memahami realitas operasional pengelolaan penilaian atas objek pajak yang dilakukan oleh Dinas Pengelolaan Keuangan Daerah Kabupaten Pasuruan dalam hal ini adalah Bidang Pendapatan. Analisis deskriptif dilakukan mulai dari tahapan pemeriksaan data primer yang langsung diberikan oleh pihak perusahaan yang akan dinilai PBB nya sebagai lampiran surat pemberitahuan objek pajak (SPOP) dan lampirannya yang selanjutnya disebut ( LSPOP).

2. Survey dilapangan

Survey dilakukan pada objek PBB yang akan dinilai dengan mencocokkan data primer yang telah dilampirkan pada SPOP dan LSPOP yang ada di Dinas Pengelolaan Keuangan Daerah (DPKD) Kabupaten Pasuruan. Survey lapangan dilakukan di dua perusahaan yang berada pada dua kecamatan yang berbeda yaitu Kecamatan Purwosari dan Kecamatan Rembang, sedangkan nama perusahaan yang berada di kecamatan tersebut adalah PT. Toyota Boshoku dan PT. Mitra Alam Segar.

3. Mereduksi data sehingga tidak terjadi overlappingpada data pembanding.

Data pembanding yang digunakan adalah data transaksi BPHTB. Data BPHTB merupakan data sekunder yang digunakan dalam penilaian untuk penentuan NJOP PBB. Data pembanding 
yang dibutuhkan untuk setiap obyek penilaian dengan menggunakan pendekatan data pasar diperlukan 3 data pembanding sehingga jika ada 2 obyek penilaian yang dilakukan data pembanding yang diperlukan ada 6 data pembanding yang berada di Kecamatan Purwosari dan Kecamatan Rembang.

4. Pembuatan kertas kerja penilaian

Kertas kerja penilaian dalam hal ini langsung di masukkan dalam aplikasi SISMIOP yang mana untuk harga satuan bangunan seharusnya menggunakan harga pasar. Satuan harga yang ada pada sitem informasi objek pajak (SISMIOP) DPKD Kabupaten Pasuruan dalam pembuatan kertas kerja penilai membuat penyesuaian sehingga opini nilai yang keluar juga sesuai dengan metode yang digunakan dalam penilaian, dalam hal ini adalah metode pendekatan harga pasar. Penyesuaian lain yang harus dilakukan adalah data pasar yang masih menggunakan data BPHTB. Pembuatan kertas kerja merupakan langkah yang paling penting dalam penentuan opini nilai yang nantinya akan tercermin NJOP dalam SPPT tahun 2015

5. Wawancara

Wawancara dilakukan secara mendalam kepada Kasi Penetapan PAD, Penilai dari KPP Pratama dan Penilai independen.Wawancara dilakukan pada Kasi Penetapan Pendapatan untuk mengetahui adanya faktor - faktor lain yang bisa mempengaruhi opini nilai yang tercermin pada SPPT PBB. Wawancara juga dilakukan kepada pengelolah properti selaku manajemen building yang mengetahui dengan baik properti yang dinilai sehingga mendapatkan data yang lebih mendalam dalam upaya memahami objek pajak. Wawancara yang dilakukan kepada penilai dari KPP Pertama terkait dengan penentuan harga pasar dan metode penilaian yang dilakukan sebelumnya oleh KPP Pratama.Wawancara juga dilakukan kepada Penilai Independen selaku sebagai tenaga ahli penilaian dalam membuat penyesuaian harga pasar sehingga opini nilai yang dihasilkan sesuai dengan pendekatan yang digunakan.

\section{HASIL DAN PEMBAHASAN}

Peneliti memilih PT.Toyota Boshoku Indonesia dan PT.Mitra Alam Segar sebagai obyek penilaian karena lokasi keduanya berada pada wilayah yang berbeda tetapi sama-sama berada didaerah industri yang ada di Kabupaten Pasuruan.Kedua perusahaan tersebut berada pada kecamatan yang berbeda dan tentu saja lingkungan yang mempengaruhi nilai dari properti - properti tersebut juga beragam.Penilaian dilakukan dengan pendekatan pasar karena pendekatan ini yang paling dianjurkan dalam Standar Penilaian Indonesia.Berikut disajikan hasil penilaian PT.Toyota Boshoku Indonesia yang dilakukan oleh peneliti dengan metode harga pasar.

\section{Proses Penilaian Perusahaan}

\section{Penilaian Tanah}

Gambar 1

Penilaian Tanah PT.Toyota Boshoku Indonesia

\begin{tabular}{|c|c|c|c|c|}
\hline \multirow{2}{*}{ URAIAN } & \multirow{2}{*}{$\begin{array}{c}\text { Objek } \\
\text { Penilaian }\end{array}$} & \multicolumn{3}{|c|}{ Data Pembanding } \\
\hline & & Data 1 & Data 2 & Data 3 \\
\hline Lokasi & Jl. Ry.Purwosari & Pucangsari Purwosari & Pucangsari Purwosari & Jl.Raya Purwodadi Km 50 \\
\hline Peruntukan & Pabrik & Tanah Kosong & Tanah Kosong & Rumah Tinggal \\
\hline Posisi & Badan & Badan / Interior & Badan / Interior & Badan / Interior \\
\hline Jenis Sertifikat & SHGB & SHM & SHM & SHM \\
\hline \multicolumn{5}{|l|}{ Nama Sumber Data } \\
\hline Status sumber data & Pemda & Perorangan & Perorangan & Properti Agen \\
\hline \multicolumn{5}{|l|}{ Telp. Sumber Data } \\
\hline Luas Tanah Sertifikat & $20.043 \mathrm{~m} 2$ & $555 \mathrm{~m} 2$ & $4540 \mathrm{~m} 2$ & $3390 \mathrm{~m} 2$ \\
\hline Luas Bangunan & $6.340 \mathrm{~m} 2$ & - & - & $200 \mathrm{~m} 2$ \\
\hline Harga penawaran & & Rp. $111,500,000$ & $\operatorname{Rp} 1,589,000,000$ & $\operatorname{Rp} \quad 1,875,000,000$ \\
\hline Nilai Bangunan/m2 & & - & - & - \\
\hline Nilai Tanah / m2 & & 200,000 & 350,000 & 550,000 \\
\hline Tanggal survey & 03/12/2014 & $03 / 12 / 2014$ & 03/12/2014 & $03 / 12 / 2014$ \\
\hline
\end{tabular}


Hasil analisis ketiga data pembanding di muka, peneliti berpendapat bahwa harga pasar tanah di daerah tersebut sekitar Rp.650.000 permeterpersegi. Jadi dengan luas tanah 20.043 nilai pasar tanah pada bulan Januari 2015 adalah Penilaian bangunan tentu saja berbeda dengan penilaian tanah meskipun sama-sama menggunakan pendekatan pasar. Penilaian bangunan bertujuaan menilai setiap bangunan dari komponen - komponen pembentuk harga bangunan permeter. Bangunan dengan jenis dan peruntukan perkantoran dengan bangunan untuk pabrik ataupun gudang memiliki komponen bangunan yang berbeda. Hal tersebut yang sebesar :Rp.13.027.950.000 (Tiga Belas Milyar Dua Puluh Tujuh Juta Sembilan Ratus Lima Puluh Ribu Rupiah).

\section{Penilaian Bangunan}

membuat harga permeter bangunan bisa sangat berbeda. Komponen bangunan pabrik dibangun dengan kontruksi rangka beton agar bisa mendukung getaran-getaran yang dihasilkan dari mesin agar bangunan tidak pecah / retak, lain halnya dengan komponen bangunan gudang yang memiliki tembok dan atap dengan bahan gulvalum.

Gambar 2

Hasil Penilaian PT.Toyota Boshoku Indonesia Oleh Peneliti

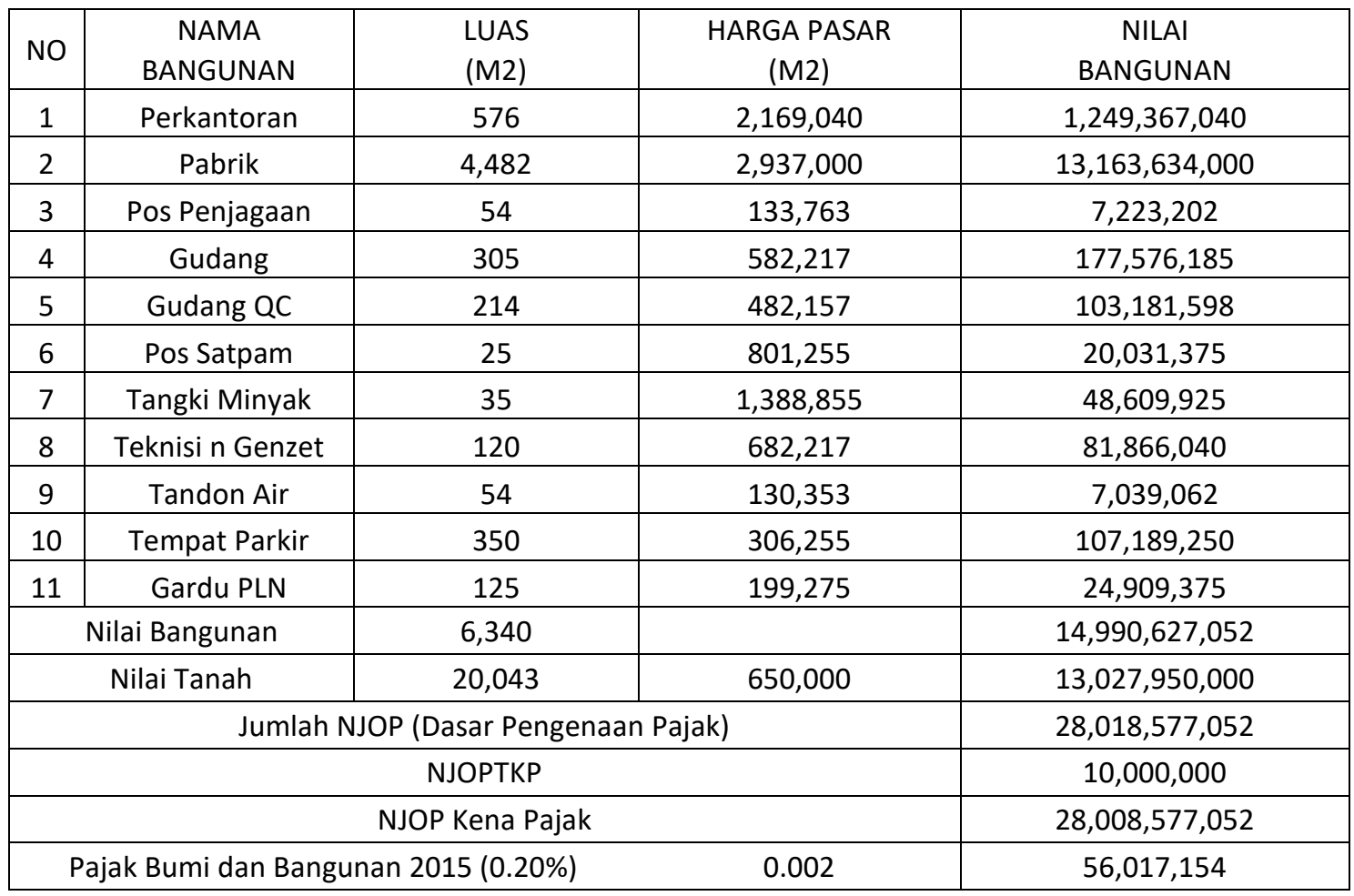

Dari table diatas dapat kita perhatikan harga pasar bangunan yang difungsikan untuk pabrik memiliki harga harga yang paling tinggi dibanding dengan harga pasar dari bangunan lain. Harga pasar bangunan pabrik mahal karena komponen bangunan tersebut dirancang khusus tahan getaran mesin yang menempel dari bangunan sehingga bangunan tidak mudah rusak. Sedangkan gedung perkantoran memiliki harga pasar permeter yang lebih tinggi dari pada harga gudang. Harga bangunan perkantoran dirancang dengan keunikan - keunikan atau tred mark dari perusahaan sehingga lebih dikenal oleh konsumen. Selain itu gedung perkantoran juga dilengkapi dengan fasiltas yang mendukung pekerjaan dikantor tersebut misalnya adanya lift yang menghubungkan lantai dasar dengan lantai yang berada diatasanya, semakin banyaknya ac yang menempel pada gedung perkantoran juga membuat harga pasar gedung perkantoran juga semakin mahal. Pada bangunan yang menyangga tangki minyak juga memiliki harga pasar yang tinggi karena bangunan tersebut juga dibuat seperti bangunan pabrik hanya saja tidak diperlukan atap, hanya dibuatkan landasan untuk 
tangki minyak saja yang terbuat dari baja.Harga pasar yang paling rendah adalah tendon air yang rangkanya terbuat dari susunan bata yang diplester. Berikut akan ditampilkan hasil perhitungan nilai tanah dan bangunan yang dilakukan oleh Pemda Kabupaten Pasuruan pada penilaian PT. TOYOTA BOSHOKU untuk Pajak Bumi dan Bangunan Tahun 2015.

Gambar 3

Hasil Penilaian PT.Toyota Boshoku Indonesia

Oleh Pemda Kab.Pasuruan

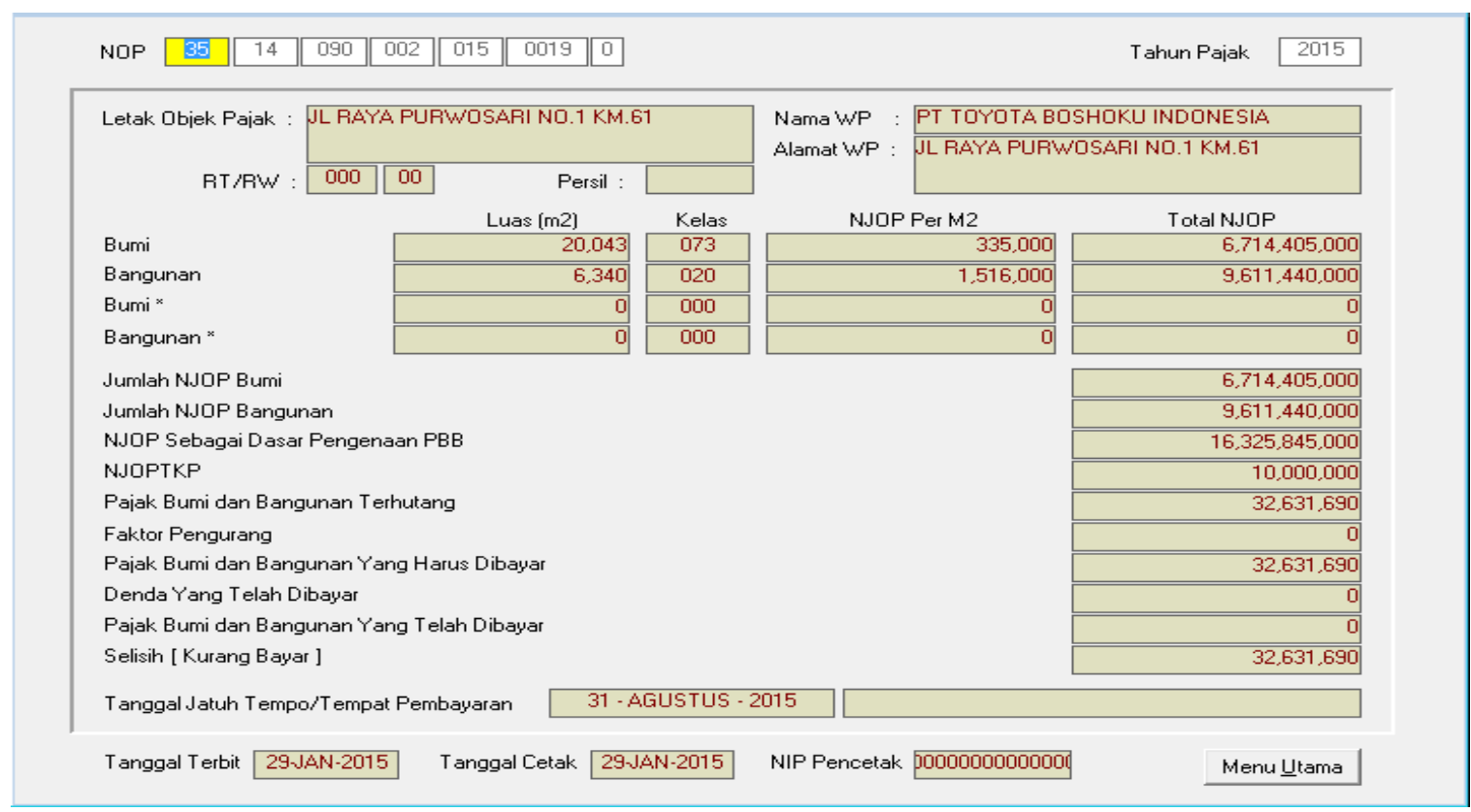

Dari perhitungan yang ada pada Gambar 2 pendekatan pasar yang dilakukan peneliti, memiliki nilai jual objek pajak yang nilainya jauh lebih besar dari pada perhitungan yang dilakukan di Pemda Kabupaten Pasuruan. NJOP yang dihasilkan oleh peneliti sebesar $\mathrm{Rp}$ $28,008,577,052,00$ sedangkan NJOP yang dihasilkan oleh Pemda Kab.Pasuruan sebesar 16.325.845.000,00. Hal tersebut terjadi karena dari komponen biaya bangun yang ada pada SISMIOP masih menggunakan dasar komponen biaya tahun 2009 tentu saja hal tersebut sangat berpengaruh. Selain itu untuk penentuan data pembanding tanah SISMIOP masih menggunakan harga transaksi pada BPHTB tahun 2014 sedangkan pada penentuan harga pasar tanah peneliti menggunakan data pembanding yang ada di pasar properti.

\section{Analisis Nilai Tanah dan Bangunan}

Nilai tanah pada penilain properti dengan pendekatan harga pasar dilakukan dengan membandingkan beberapa harga properti pada pasar properti dengan mencari kualifikasi properti yang identik dan lokasinya tidak jauh dari objek penilaian.

Nilai bangunan suatu properti tergantung dari komponen biaya bangun properti yang membentuknya.Properti yang digunakan untuk gedung perkantoran dan untuk bangunan pabrik tentu saja memiliki komponen bangunan yang berbeda. Dari perbedaan kompenen bangun yang berbeda itulah yang membuat nilai bangunan untuk setiap bangunan tidak sama.

\section{FAKTOR - FAKTOR YANG MEMPENGARUHI NJOP}

Berdasarkan hasil wawancara yang dilakukan kepada penilai dari penilai dari KPP Pertama, Penilai Independen dan Kasi Penetapan PAD Pemda Kabupaten Pasuruan ada beberapa faktor yang mempengaruhi NJOP PBB yaitu faktor internal merupakan faktor yang melekat pada properti itu sendiri sedangkan faktor eksternal adalah faktor yang berkaiatan dengan kebijakan pemerintah dan permintaan pasar. Lokasi Objek Pajak

1. Lokasi merupakan faktor utama penentu nilai suatu objek penilaian. Lokasi yang strategis dan kemudahaan mengakses akan memberikan kontribusi yang paling besar terhadap suatu objek penilaian. Jika suatu bangunan perkantoran dibangun pada lokasi / daerah kumuh maka tidak ada seorang investor yang memilih lokasi tersebut sebagai tempat untuk mengembangkan usahanya. Lain halnya jika gedung perkantoran dibangun di pusat kota yang dilengkapi dengan fasilitas dan saran 
transportasi yang memadai maka nilai properti pasti bernilai tinggi karena mudah dijangkau dan pasti banyak didukung fasilatas lain yang membuat kegiatan bisnis berkembang pesat. Faktor lokasi sangat berhubungan erat dengan prinsip higest and best use dan prinsip confirmity dimana ketepatan lokasi membangun properti sesuai dengan kebutuhan masyarakat. Keadan Fisik Objek Penilaian

2. Keadaan fisik objek penilaian yang dimaksud adalah kondisi tanah atau bangunan yang memberikan kontribusi yang besar pada nilai suatu bangunan. Umur ekonomis suatu bangunan mempengaruhi nilai suatu objek penilaian. Seorang investor akan mempertimbangkan kondisi bangunan terkait dengan perawatan gedung. Bangunan yang terawat akan menambah umur ekonomis bangunan. Selain umur ekonomis kesesuaian bentuk bangunan juga menjadi bahan pertimbangan.

Selain faktor internal yang telah disebutkan dimuka ada faktor eksternal yang mempengaruhi besar kecilnya NJOP PBB yaitu kebijakan pemerintah dan permintaan pasar. Dalam menentukan besarnya PBB Pemerintah Kabupaten Pasuruan berasaskan keadilan, karena dalam menetapkan besarnya PBB nilai yang ditetapkan tidak akan menimbulkan kelebihan beban. Pajak yang dibebankan pada masyarakat disesuaikan dengan kemampuan membayar, percuma saja jika pajak ditetapkan besar tapi masyarakat tidak mampu untuk membayar. Faktor eksternal yang kedua adalah permintaan pasar. Dalam hal ini permintaan pasar yang dimaksud adalah banyaknya investor yang mau berinvestasi di Kabupaten Pasuruan. Banyaknya investor yang ingin membangun usaha baik untuk pendirian pabrik ataupun perumahan sangat mempengaruhi harga tanah di Kabupaten Pasuruan.

\section{KESIMPULAN}

Penilaian PBB perusahaan yang dilakukan oleh Pemda Kabupaten Pasuruan Tahun 2014 untuk SPPT 2015 menggunakan metode harga pasar belum sesuai dengan Standar Penilaian Indonesia.Penilaian properti menggunakan pendekatan harga pasar merupakan suatu proses penilaian yang menghasilkan opini nilai yang dihasilkan dari membandingkan aset lain yang serupa/identik yang ada dipasar properti di sekitar objek penilaian. Penilaian properti meliputi penilaian tanah dan bangunan, kenaikan harga keduanya berjalan seiring dengan kebutuhan masyarakat.Nilai tanah semakin lama semakin naik karena tanah tidak mengenal penyusutan, lain halnya dengan bangunan.Bangunan setiap tahunnya ada penyusutan sehingga nilai bangunan kian lama kian turun.

Faktor internal yang mempengaruhi Nilai Jual Objek Pajak PBB adalah :

a. Lokasi Objek Pajak

Lokasi merupakan faktor utama penentu nilai suatu objek penilaian

b. Keadaan fisik objek penilaian yang dimaksud adalah kondisi tanah atau bangunan yang memberikan kontribusi yang besar pada nilai suatu bangunan

\section{UCAPAN TERIMA KASIH}

Dengan mengucapkan puji syukur kehadirat Allah SWT tidak lupa saya ucapkan terimakasih yang sebesar - besarnya kepada Bapak Ali Djamhuri, SE.,M.Com.,PhD.,CPA.,AK selaku pembimbing pertama dan Bapak Nurkholis, SE.,M.Buss.,PhD.,Ak selaku pembimbing kedua. Keduanya telah dengan ikhlas membimbing dan mengarahkan penulis sehingga penulisan karya ilmiah ini telah selasai dengan baik dengan waktu yang cukup singkat.

\section{DAFTAR PUSTAKA}

[1]. Prawoto, Agus. 2012.Teori \& praktek Penilaian Properti, Edisi Kedua.BPFE. Yogyakarta

[2]. Andrew A and Pitt, M. 2004. Property Appraisal in Government, Journal Of Property Investment \& Finance. Vol.22, No.2 pp.192-199

[3]. Peto, French N and Bowman, G. 1996. Developments In Valuation Methodology. Journal of Property Valuation \& Investment.Vol 14 No.4 pp.79-100

[4]. KPPSPI. 2013, KEPI \& SPI 2013, MAPPI, Jakarta

[5]. Hermit, Herman. 2009. Teknik Penaksiran Harga Tanah Perkotaan. Cetakan Kesatu. Mandar Maju. Bandung

[6]. Moleong, Lezy. J. 2010. Metode Penelitian Kualitatif. Cetakan Keduapuluh delapan. PT. Remaja Rosdakarya. Bandung.

[7]. O'Brien, Rory. 1998. The Methodological Approach of Action Research. http://web.net/robrien/papers/arfinal.html. Diakses 25 Juli 2015.

[8]. McNiff J and Whitehead Jack. 2006. Action Research. First Published. SAGE Publications Ltd. London 